\title{
Implication from thyroid function decreasing during chemotherapy in breast cancer patients: chemosensitization role of triiodothyronine
}

Jianbo Huang, Liangbin Jin ${ }^{\dagger}$, Guangyan Ji, Lei Xing ${ }^{\dagger}$, Chaobo Xu, Xiong Xiong, Hongyuan Li, Kainan Wu, Guosheng Ren ${ }^{*}$ and Lingquan Kong*

\begin{abstract}
Background: Thyroid hormones have been shown to regulate breast cancer cells growth, the absence or reduction of thyroid hormones in cells could provoke a proliferation arrest in G0-G1 or weak mitochondrial activity, which makes cells insensitive to therapies for cancers through transforming into low metabolism status. This biological phenomenon may help explain why treatment efficacy and prognosis vary among breast cancer patients having hypothyroid, hyperthyroid and normal function. Nevertheless, the abnormal thyroid function in breast cancer patients has been considered being mainly caused by thyroid diseases, few studied influence of chemotherapy on thyroid function and whether its alteration during chemotherapy can influence the respose to chemotherapy is still unclear. So, we aimed to find the alterations of thyroid function and non-thyroidal illness syndrome (NTIS) prevalence druing chemotherapy in breast cancer patients, and investigate the influence of thyroid hormones on chemotherapeutic efficacy.
\end{abstract}

Methods: Thyroid hormones and NTIS prevalence at initial diagnosis and during chemotherapy were analyzed in 685 breast diseases patients (369 breast cancer, 316 breast benign lesions). The influence of thyroid hormones on chemotherapeutic efficacy was evaluated by chemosensitization test, to compare chemotherapeutic efficacy between breast cancer cells with chemotherapeutics plus triiodothyronine $\left(T_{3}\right)$ and chemotherapeutics only.

Results: In breast cancer, NTIS prevalence at the initial diagnosis was higher and increased during chemotherapy, but declined before the next chemotherapeutic course. Thyroid hormones decreased signigicantly during chemotherapy. $\mathrm{T}_{3}$ can enhance the chemosensitivity of MCF-7 to 5-Fu and taxol, with progression from G0-G1 phase to $\mathrm{S}$ phase. The similar chemosensitization role of $\mathrm{T}_{3}$ were found in MDA-MB-231. We compared chemotherapeutic efficacy among groups with different usage modes of $\mathrm{T}_{3}$, finding pretreatment with lower dose of $T_{3}$, using higher dose of $T_{3}$ together with 5-Fu or during chemotherapy with 5-Fu were all available to achieve chemosensitization, but pretreatment with lower dose of $\mathrm{T}_{3}$ until the end of chemotherapy may be a safer and more efficient therapy.

Conclusions: Taken together, thyroid hormones decreasing during chemotherapy was found in lots of breast cancer patients. On the other hand, thyroid hormones can enhance the chemotherapeutic efficacy through gatherring tumor cells in actively proliferating stage, which may provide a new adjuvant therapy for breast cancer in furture, especially for those have hypothyroidism during chemotherapy.

Keywords: Breast cancer, Thyroid hormones, Non-thyroidal illness syndrome, Chemotherapeutic efficacy

\footnotetext{
*Correspondence: rgs726@163.com; huihuikp@163.com

'Equal contributors

Department of Endocrine \& Breast Surgery, the First Affiliated Hospital of

Chongqing Medical University, You Yi Rd. 1, Chongqing, People's Republic of China
}

\section{Biomed Central}

(c) 2013 Huang et al.; licensee BioMed Central Ltd. This is an Open Access article distributed under the terms of the Creative Commons Attribution License (http://creativecommons.org/licenses/by/2.0), which permits unrestricted use, distribution, and reproduction in any medium, provided the original work is properly cited. 


\section{Background}

Thyroid hormones, which function in cell development, differentiation, growth, and other aspects of metabolism, are regulated by hypothalamic-pituitary axis. In cancer patients, thyroid function is thought to be vulnerable to chemotherapy, as hypothalamic-pituitary axis is active and chemotherapy is systemic therapy for patients. The influence of chemotherapy on thyroid function was just seen as a late effect [1,2], mainly presenting hypothyroidism. Nevertheless, thyroid function decreasing does not occur in all cancer patients receiving chemotherapy, thyroxine $\left(\mathrm{T}_{4}\right), \mathrm{T}_{3}$ and reverse triiodothyronine $\left(\mathrm{rT}_{3}\right)$ levels of patients with nonseminoma testicular carcinoma increased significantly during chemotherapy [3], some choriocarcinoma patients even suffered thyroid crisis during chemotherapy $[4,5]$, the cause may be the high levels of human chorionic gonadotrophin (HCG), producing biochemical and clinical hyperthyroidism [6]. While, nonseminoma testicular carcinoma and choriocarcinoma are rare human malignancies that are highly curable with chemotherapy or combination of surgery and chemotherapy, even with widespread metastases. For breast cancer patients, studies did not directly show chemotherapy can influence thyroid function, only found some results indicative hypothyroidism, such as elevated concentrations of thyroid stimulating hormone (TSH), thyroperoxidase antibody (anti-TPO), thyroglobulin antibody (anti-Tg) [7] and decreased $\mathrm{T}_{3}$ uptake levels [8]. Few studied the alteration of thyroid function in breast cancer patients during chemotherapy, the time that chemotherapeutic reagents take effect in.

On the other hand, chemotherapeutic efficacy can be influenced by certain endocrine hormones or related therapy. In vivo, rat treated with growth hormone and chemotherapy had better efficacy than those treated with chemotherapy only [9]. In clinic, tamoxifen, which competitively combine with estrogen receptor, can not be concurrently used with chemotherapy for breast cancer patients, as the cancer growth inhibition by tamoxifen makes tumor cells insensitive to chemotherapy. Interestingly, choriocarcinoma and testicular carcinoma are highly curable with chemotherapy, even with widespread metastases, they have elevated thyroid hormones in common during chemotherapy, is better chemotherapeutic efficacy related with elevated thyroid hormones? Whether $\mathrm{T}_{3}$ can enhance sensitivity of breast cancer cells to chemotherapy is unclear.

In this study, 1698 serum samples in 685 cases of breast diseases, including 369 cases of breast cancer and 316 cases of breast benign lesions were analyzed to study the thyroid hormones and NTIS prevalence in breast cancer patients at initial diagnosis and during chemotherapy.
According to the changes of thyroid hormones during chemotherapy, the effect of $T_{3}$ on sensitity of breast cancer cells to chemotherapy was studied.

\section{Methods}

\section{Patients and samples}

A total of 685 female patients with breast diseases admitted in the First Affiliated Hospital of Chongqing Medical University, with median age of 49 years (range 17-81 years) was studied, including 316 cases of breast benign lesions, such as fibroadenoma, mastopathy, intraductal papilloma, lipoma, etc. and 369 cases of breast carcinoma, among which 224 cases were initially diagnosed with breast carcinoma. All breast diseases were confirmed by the pathology. No history of thyroidal diseases or liver, renal dysfunction was found in these patients. All breast cancer patients were treated with standard chemotherapy. A total of 1698 samples were collected from all patients on the first admission and / or 1 to 3 days before and / or 1 to 3 days after each cycle chemotherapy.

Ethical approval for this study and agreement by all patients were obtained from the Biomedicine Ethics Committee of The First Affiliated Hospital of Chongqing Medical University. Each subject signed an agreement of participation in this study that was approved by Biomedicine Ethics Committee of The First Affiliated Hospital of Chongqing Medical University and consented to publish. The protocol of the study adhered to the tenets of the Declaration of Helsinki and was approved by the local ethics committee.

\section{Thyroid function assay}

$\mathrm{T}_{3}, \mathrm{~T}_{4}$, free triiodothyronine $\left(\mathrm{FT}_{3}\right)$, free thyroxine $\left(\mathrm{FT}_{4}\right)$, TSH were detected by UnicelTM DXI 800 with chemiluminescence methods in the Laboratory of Endocrinology of the First Affiliated Hospital of Chongqing Medical University.

\section{Cell line and cell culture}

The MCF-7, MDA-MB-231 breast cancer cell lines were supported by Molecular Oncology and Epigenetics Laboratory, the First Affiliated Hospital of Chongqing Medical University. The cell lines were maintained in RPMI 1640 (Gibco-BRL, Karlsruhe, Germany) supplemented with $10 \%$ fetal bovine serum (FBS) (PAA Laboratories, Linz, Austria), $100 \mathrm{U} / \mathrm{ml}$ penicillin and $100 \mathrm{mg} / \mathrm{ml}$ streptomycin, at $37^{\circ} \mathrm{C}$ in a humidified atmosphere containing $5 \% \mathrm{CO}_{2}$.

\section{Chemosensitization test and reagents}

The chemosensitization role of $\mathrm{T}_{3}$ (Sigma Aldrich, Italy) is reflected by changes of sensitivity of breast cancer cells to 5-fluorouracil (5-Fu) (Xu Dong, China) or Taxol (De Bao, China). The concentration of $\mathrm{T}_{3}$ used for 
chemosensitization test ranged from $2 \mathrm{ng} / \mathrm{ml}$ to $32 \mathrm{ng} / \mathrm{ml}$, 5-Fu and Taxol were used at the $\mathrm{IC}_{50}$ concentration for each cell line (5-Fu: $13 \mu \mathrm{mol} / \mathrm{L}$ for MCF-7, $8 \mu \mathrm{mol} / \mathrm{L}$ for MDA-MB-231; Taxol: $0.4 \mu \mathrm{mol} / \mathrm{L}$ for MCF-7, $0.5 \mu \mathrm{mol} / \mathrm{L}$ for MDA-MB-231). According to different concentrations of $\mathrm{T}_{3}$, the chemosensitization test comprised nine independent tests, each contained eight groups with a specific $\mathrm{T}_{3}$ concentration (Figure 1). Before chemosensitization test began, the MCF-7 cells in logarithmic growth phase were trypsinized and seeded at a density of 3000/well into 96-well plates at $37^{\circ} \mathrm{C}$ in $5 \%$ incubator. After $21 \mathrm{~h}$, the chemosensitization test began.

The 1 st to 3 rd groups were pretreated with $T_{3}$ for 24 $\mathrm{h}$, then treated with 5 -Fu for $48 \mathrm{~h}$, the depriving times of $\mathrm{T}_{3}$ were different, the 1 st group was kept with $\mathrm{T}_{3}$ until test end, $\mathrm{T}_{3}$ of the 2 nd group was deprived at the start of $5-\mathrm{Fu}$, and $\mathrm{T}_{3}$ of the 3rd group was deprived after using 5 -Fu for $24 \mathrm{~h}$.

After $24 \mathrm{~h}$ without $\mathrm{T}_{3}$ pretreatment, the 4th to 6 th groups were also treated with 5 -Fu for $48 \mathrm{~h}$. The 4 th group was added with $\mathrm{T}_{3}$ at the start of 5 -Fu until test end, $\mathrm{T}_{3}$ of the 5 th group was added at the start of $5-\mathrm{Fu}$ and deprived after using for $24 \mathrm{~h}, \mathrm{~T}_{3}$ of the 6th group was added when 5 -Fu was added for $24 \mathrm{~h}$.

After $24 \mathrm{~h}$ without $\mathrm{T}_{3}$ pretreatment, the 7 th group was treated with 5 -Fu only for $48 \mathrm{~h}$, and without treating with $\mathrm{T}_{3}$. The 8 th group was set as control group, without treating with $\mathrm{T}_{3}$ or 5 -Fu.

\section{Cell proliferation assay and inhibition ratio calculation}

Before cell proliferation assay, wells of all groups were washed with PBS for two times, replaced with fresh culture medium, and set one new group with culture medium only as blank control. Cell counting kit-8 (CCK8) (Dojindo Laboratories, Japan) was used to evaluate the viability of cells in all groups according to the instructions of the manufacturer. The final concentration used for assay was $10 \%$, after incubation with cells for $1 \mathrm{~h}$ at $37^{\circ} \mathrm{C}$ to allow CCK8 to form formazan crystals by reacting with metabolical active cells, the OD value was measured in a microplate reader at $450 \mathrm{~nm}$. The inhibition ratio was calculated by following formula: 1-OD value of treated group / OD value of control group. All experiments were repeated at least three times by same person.

\section{Flow cytometry analysis of cell cycle}

Flow cytometry analysis of cell cycle was implemented as previously reported [10]. For cell cycle analysis, cells were fixed in ice-cold $70 \%$ ethanol and stained with propidium iodide (PI). The cell cycle profiles were assayed using the Elite ESP flow cytometry at $488 \mathrm{~nm}$, and the data were analyzed using the CELL Quest software (BD Biosciences, San Jose, CA). Flow cytometric analysis was immediately performed.

\section{Statistical analysis}

All statistical analyses were performed using SPSS 18.0 statistical software. The Student's t-test was used to compare thyroid function between patients of benign lesions and cancer, the comparison of thyroid function between postchemotherapy and prechemotherapy, thyroid function between two consecutive prechemotherapies were performed with paired statistical comparison, the nonparametric test was used when equal variances is not assumed. The Anova or the nonparametric tests were applied to compare the proportion of tumor cells in $\mathrm{S}$ phase between treated and control group, inhibition ratios among seven different treated groups. Results of thyroid functions were presented as mean $\pm \mathrm{SD}$, values of $P \leq 0.05$ were considered significant.
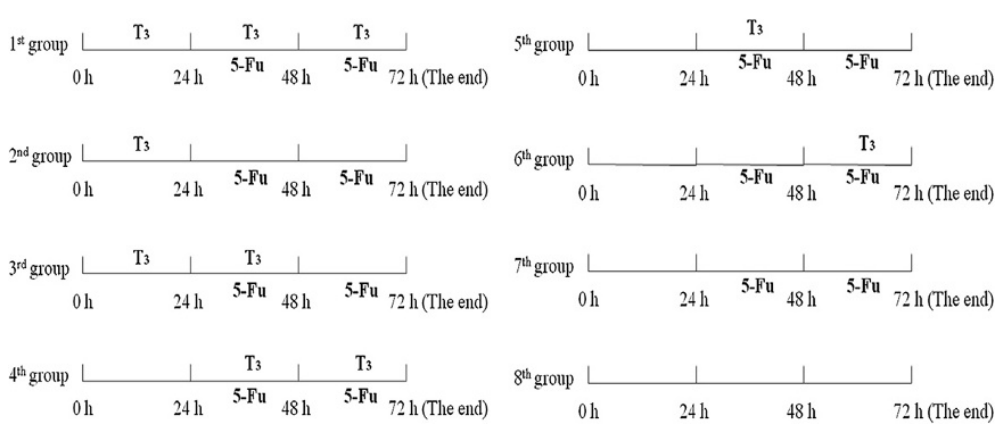

Figure 1 The illustration for chemosensitization test with different group. The 1st to 3rd groups were pretreated with $T_{3}$ for $24 \mathrm{~h}$, then treated with 5-Fu for $48 \mathrm{~h}$, the depriving times of $T_{3}$ were different, the 1st group was kept with $T_{3}$ until test end, $T_{3}$ of the 2 nd group was deprived at the start of 5-Fu, and $\mathrm{T}_{3}$ of the 3 rd group was deprived after using 5-Fu for $24 \mathrm{~h}$. After $24 \mathrm{~h}$ without $\mathrm{T}_{3}$ pretreatment, the 4 th to 6 th groups were also treated with 5 -Fu for $48 \mathrm{~h}$. The 4 th group was added with $T_{3}$ at the start of 5 -Fu until test end, $T_{3}$ of the 5 th group was added at the start of 5-Fu and deprived after using for $24 \mathrm{~h}$, $\mathrm{T}_{3}$ of the 6 th was added when 5-Fu was added for $24 \mathrm{~h}$. After $24 \mathrm{~h}$ without $\mathrm{T}_{3}$ pretreatment, the 7th group was treated with 5-Fu only for $48 \mathrm{~h}$, and without treating with $\mathrm{T}_{3}$. The 8th group was set as control group, without treating with $\mathrm{T}_{3}$ or $5-\mathrm{Fu}$. 


\section{Results}

Thyroid function of patients with breast benign lesions and breast cancer

A total of 224 serum samples of breast cancer patients and 316 samples of breast benign lesion patients at initial diagnosis were analyzed for thyroid hormones. Thirty-seven of 224 breast cancer patients were diagnosed as NTIS (either $\mathrm{FT}_{3}$ or $\mathrm{FT}_{4}$ is below the normal), of which the morbidity was higher than that in breast benign lesions patients (16.5\% vs $7.3 \%$ ). The mean concentrations of $\mathrm{T}_{3}, \mathrm{FT}_{3}$ in breast cancer patients were lower than that in breast benign lesions patients, however, only difference of $\mathrm{T}_{3}$ between them was statistically significant $(P<0.05)$. On contrary, the mean concentrations of $\mathrm{T}_{4}$ and $\mathrm{TSH}$ were higher in breast cancer patients, but only difference of $\mathrm{T}_{4}$ between them was statistically significant $(P \leq 0.05)$ (Table 1$)$.

\section{Alterations of thyroid function in breast cancer patients during chemotherapy}

Blood samples from 180 cases of breast cancer patients were analyzed in this part. Eighty-two point two percent (82.2\%) patients suffered NTIS during chemotherapy. $\mathrm{T}_{3}$, $\mathrm{T}_{4}, \mathrm{FT}_{3}, \mathrm{TSH}$ decreased and $\mathrm{FT}_{4}$ increased significantly during chemotherapy compared with prechemotherapy $(P<0.05)$ (Table 2).

\section{Comparison of thyroid function between two consecutive prechemotherapies}

A total of 456 samples were analyzed between two consecutive prechemotherapies, no significant differences of thyroid function were found $(P>0.05)$ (Table 3$)$.

\section{The chemosensitization test of triiodothyronine}

The thyroid functions decreasing during chemotherapy indicated adding thyroid hormones may enhance the sensitivity of tumor cells to chemotherapy, as $\mathrm{T}_{3}$ can induce cells progression from G0-G1 phase to $S$ phase [11] or enhance mitochondrial activity [12] which makes tumor cells more sensitive to chemotherapy. So, as the specific chemotherapeutic reagent for killing tumor cells in $S$ phase, 5-Fu was choosed to study the change of sensitivity of breast cancer cells when $T_{3}$ was present. Three groups were set up, cells were seeded in quintuplicate in 96-well plate at a density of $3 \times 10^{3}$ cells/well. The 1 st group was treated with $\mathrm{T}_{3}$ and 5 $\mathrm{Fu}$, the 2nd group was treated with 5 -Fu only, the 3rd group was set as control group. We firstly used $4 \mathrm{ng} / \mathrm{ml} \mathrm{T}_{3}$ to pretreat MCF-7 or MDA-MB-231 for $24 \mathrm{~h}$, then 5 -Fu was added and $\mathrm{T}_{3}$ were deprived, values of OD after $48 \mathrm{~h}$ were measured, the results showed that both MCF-7 and MDA-MB-231 pretreated with $\mathrm{T}_{3}$ were more sensitive to

Table 1 Comparison of thyroid function between patients of breast benign lesions and cancer on initial diagnosis (mean \pm SD)

\begin{tabular}{|c|c|c|c|}
\hline Thyroid functions & Breast benign lesions patients $(n=316)$ & Breast cancer patients $(n=224)$ & $p$ value \\
\hline $\mathrm{T}_{3}(\mathrm{ng} / \mathrm{ml})$ & $1.22 \pm 0.23^{*}$ & $1.16 \pm 0.25$ & 0.002 \\
\hline $\mathrm{T}_{4}(\mu \mathrm{g} / \mathrm{dl})$ & $7.12 \pm 1.22^{*}$ & $7.34 \pm 1.36$ & 0.050 \\
\hline $\mathrm{FT}_{3}(\mathrm{pg} / \mathrm{ml})$ & $2.92 \pm 0.43$ & $2.87 \pm 0.38$ & 0.149 \\
\hline $\mathrm{FT}_{4}(\mathrm{ng} / \mathrm{dl})$ & $0.89 \pm 0.13$ & $0.89 \pm 0.18$ & 0.650 \\
\hline TSH ( $\mu \mathrm{lU} / \mathrm{ml})$ & $3.16 \pm 4.92$ & $3.92 \pm 8.40$ & 0.187 \\
\hline \multicolumn{2}{|c|}{ Clinicopathological features of breast cancer } & \multicolumn{2}{|l|}{ Number } \\
\hline \multirow[t]{5}{*}{ Tumor size } & T0 (impalpable) & 11 & \\
\hline & $\mathrm{T} 1(\leq 2 \mathrm{~cm})$ & 84 & \\
\hline & $\mathrm{T} 2(>2 \mathrm{~cm}, \leq 5 \mathrm{~cm})$ & 105 & \\
\hline & $\mathrm{T} 3(>5 \mathrm{~cm})$ & 19 & \\
\hline & Unknown & 5 & \\
\hline \multirow[t]{4}{*}{ Tumor grade } & । & 11 & \\
\hline & $\|$ & 188 & \\
\hline & III & 19 & \\
\hline & Unknown & 6 & \\
\hline \multirow[t]{6}{*}{ Clinical stage } & 0 & 9 & \\
\hline & I & 63 & \\
\hline & $\|$ & 132 & \\
\hline & III & 11 & \\
\hline & IV & 4 & \\
\hline & Unknown & 5 & \\
\hline
\end{tabular}


Table 2 Comparison of thyroid function in breast cancer patients between prechemotherapy and postchemotherapy (mean \pm SD)

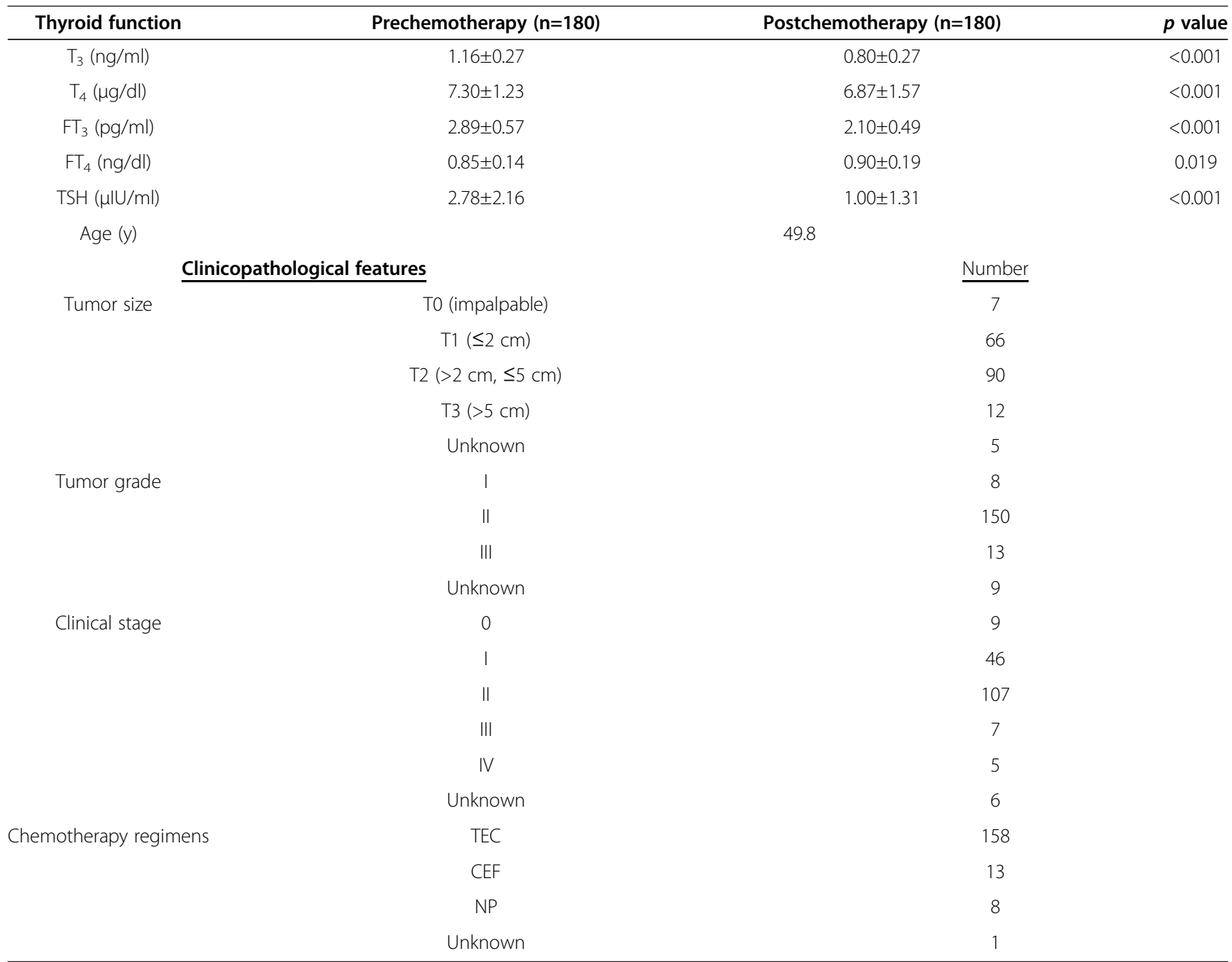

TEC: Docetaxel, Epirubicin, Cyclophosphamide.

CEF: Cyclophosphamide, Epirubicin, Fluorouracil.

NP: Navelbine, Cisplati.

5-Fu than those with 5 -Fu only, without $\mathrm{T}_{3}$ pretreatment $(P<0.05)$ (Figure $2 \mathrm{~A}$ and $2 \mathrm{~B})$.

The 5-Fu especially targets tumor cells in $\mathrm{S}$ phase, to study whether enhancement of sensitivity of tumor cells to 5 -Fu was related with increasing proportion of breast cancer cells in S phase, we further investigated the effect of $\mathrm{T}_{3}$ on MCF-7 cell cycle. Representative results of cellcycle distribution in MCF-7 pretreated with $\mathrm{T}_{3}$ or without $\mathrm{T}_{3}$ were shown in Figure 2C. Flow cytometry analysis revealed a statistically significant increase in the number of $\mathrm{T}_{3}$ pretreated MCF-7 with $\mathrm{S}$ phase $(P<0.05)$, accompanied with the increase in G2-M phase and decrease in G0G1 phase $(P<0.05)$ (Figure 2D). So, $\mathrm{T}_{3}$ enhanced the sensitivity of MCF-7 to 5-Fu, through promoting the cell cycle progression of MCF-7 from G0-G1 phase to S phase.

Besides discussing the effect of thyroid hormone on $5-\mathrm{Fu}$, we also observed whether $T_{3}$ has the chemosensitization role for Taxol. Taxol works differently by arresting the cells in G2-M phase, considering a higher concentration of $\mathrm{T}_{3}$ may be more efficient in promoting breast cancer cells proliferation, we used $24 \mathrm{ng} / \mathrm{ml} \mathrm{T}_{3}$ to pretreat MCF-7 or MDA-MB-231, the results showed that both MCF-7 and MDA-MB-231 pretreated with $T_{3}$ were more sensitive to Taxol than those with Taxol only, without $\mathrm{T}_{3}$ pretreatment $(P<0.05)$ (Figure 2E and 2F).

\section{The different usage modes of triiodothyronine on} chemosensitivity of MCF-7

Considering the thyroid function decrease during chemotherapy, which may induce breast cancer cells retardant in G0 phase, and $\mathrm{T}_{3}$ could enhance chemosensitivity of MCF-7 through increasing proportion of cells in $S$ phase, we thought $\mathrm{T}_{3}$ may be used as a new adjuvant therapy for breast cancer, and started to 
Table 3 Comparison of thyroid function in breast cancer patients between two consecutive prechemotherapies (mean \pm SD)

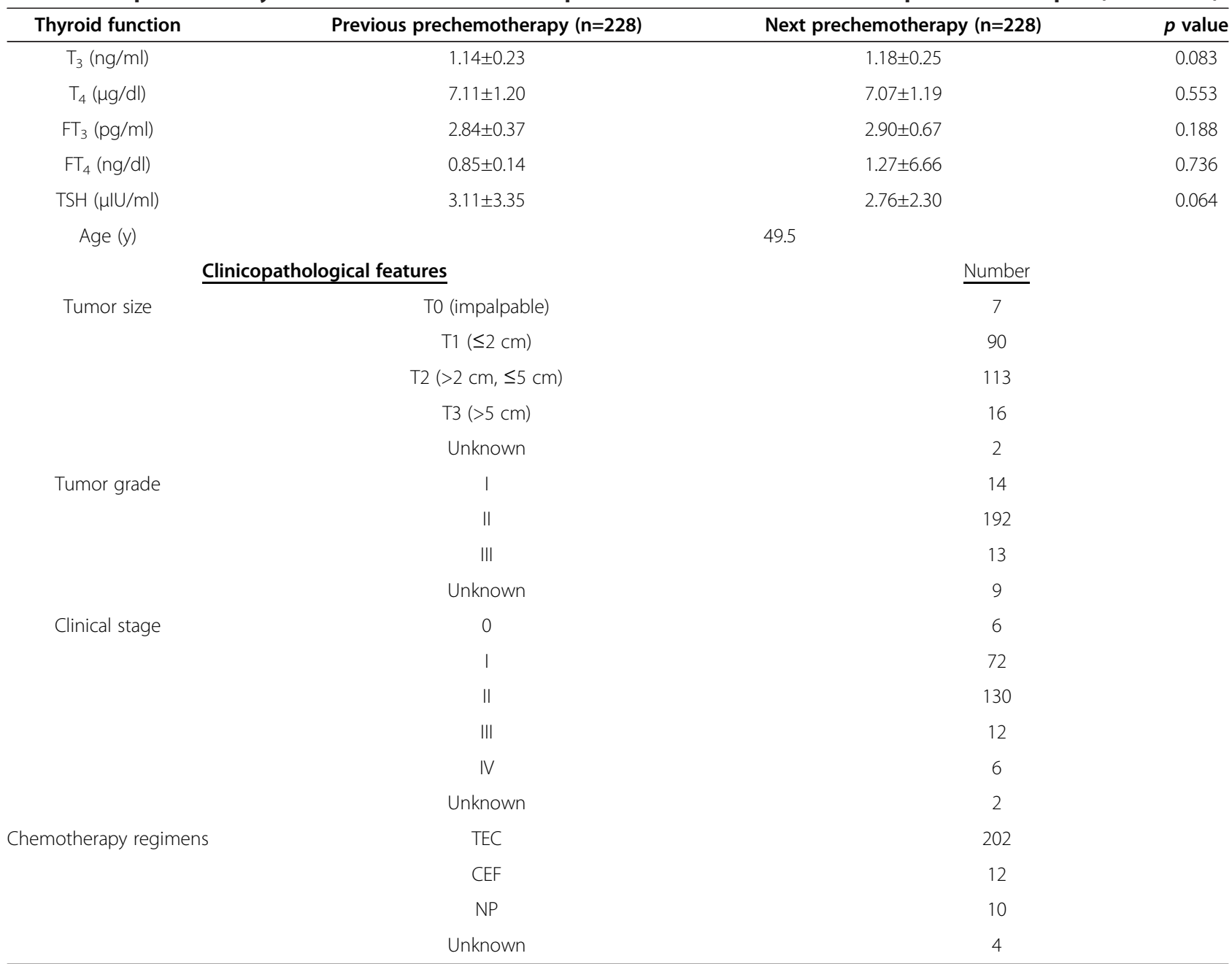

TEC: Docetaxel, Epirubicin, Cyclophosphamide.

CEF: Cyclophosphamide, Epirubicin, Fluorouracil.

NP: Navelbine, Cisplatin.

study the efficacy of different $\mathrm{T}_{3}$ using modes on chemosensitivity of MCF-7.

Eight groups were set as described in methods. As $4 \mathrm{ng} / \mathrm{ml} \mathrm{T}_{3}$ had been proved to have chemosensitization role by us, we then firstly use $4 \mathrm{ng} / \mathrm{ml}$ with different usage modes to study the efficacy of $\mathrm{T}_{3}$ on chemosensitivity of MCF-7. Surprisingly, only sensitivity of MCF-7 to 5-Fu in the first three groups pretreated with $\mathrm{T}_{3}$ significantly increased $(P<0.05)$, no chemosensitization was found in the 4 th to 6 th groups (Figure $3 \mathrm{~A})$.

Whether elevating the $\mathrm{T}_{3}$ dose can enhance the chemosensitivity of MCF-7 in 4th to 6th groups, those without $\mathrm{T}_{3}$ pretreatment, and decreasing $\mathrm{T}_{3}$ could reduce the chemosensitivity in the 1 st to 3 rd groups, those were pretreated with $T_{3}$, were still unclear. So, we performed eight other chemosensitization tests with $\mathrm{T}_{3}$ at $2 \mathrm{ng} / \mathrm{ml}, 8 \mathrm{ng} / \mathrm{ml}, 12 \mathrm{ng} / \mathrm{ml}, 16 \mathrm{ng} / \mathrm{ml}, 20 \mathrm{ng} / \mathrm{ml}, 24$ $\mathrm{ng} / \mathrm{ml}, 28 \mathrm{ng} / \mathrm{ml}, 32 \mathrm{ng} / \mathrm{ml}$, using the concentrations of
$\mathrm{T}_{3}$ more than $4 \mathrm{ng} / \mathrm{ml}(8 \mathrm{ng} / \mathrm{ml}$ to $32 \mathrm{ng} / \mathrm{ml})$ is to imitate the hyperthyroidism in choriocarcinoma patients receiving chemotherapy. The results showed $2 \mathrm{ng} / \mathrm{ml} \mathrm{T}_{3}$ was not efficient enough to enhance the chemosensitivity of MCF-7 to $5-\mathrm{Fu}$ in any group $(P>0.05)$ (Figure $3 \mathrm{~B}$ ), which indicated the suitable dose of $\mathrm{T}_{3}$ is essential point for chemosensitization. On the contrary, the MCF-7 in 4th to 6th groups successively showed significantly increased chemosensitivity, compared with that of 7 th group $(P<0.05)$, as the $\mathrm{T}_{3}$ dose elevating from $8 \mathrm{ng} /$ $\mathrm{ml}$ to $32 \mathrm{ng} / \mathrm{ml}$ (Figure $3 \mathrm{C}$ ).

\section{Discussion}

Abnormal thyroid function in breast cancer patients at initial diagnosis

Many non-thyroidal illness may affect the thyoid function and induce NTIS [13], which is also called euthyroid sick syndrome (ESS) [14], low $\mathrm{T}_{3}$ or $\mathrm{T}_{4}$ syndrome 


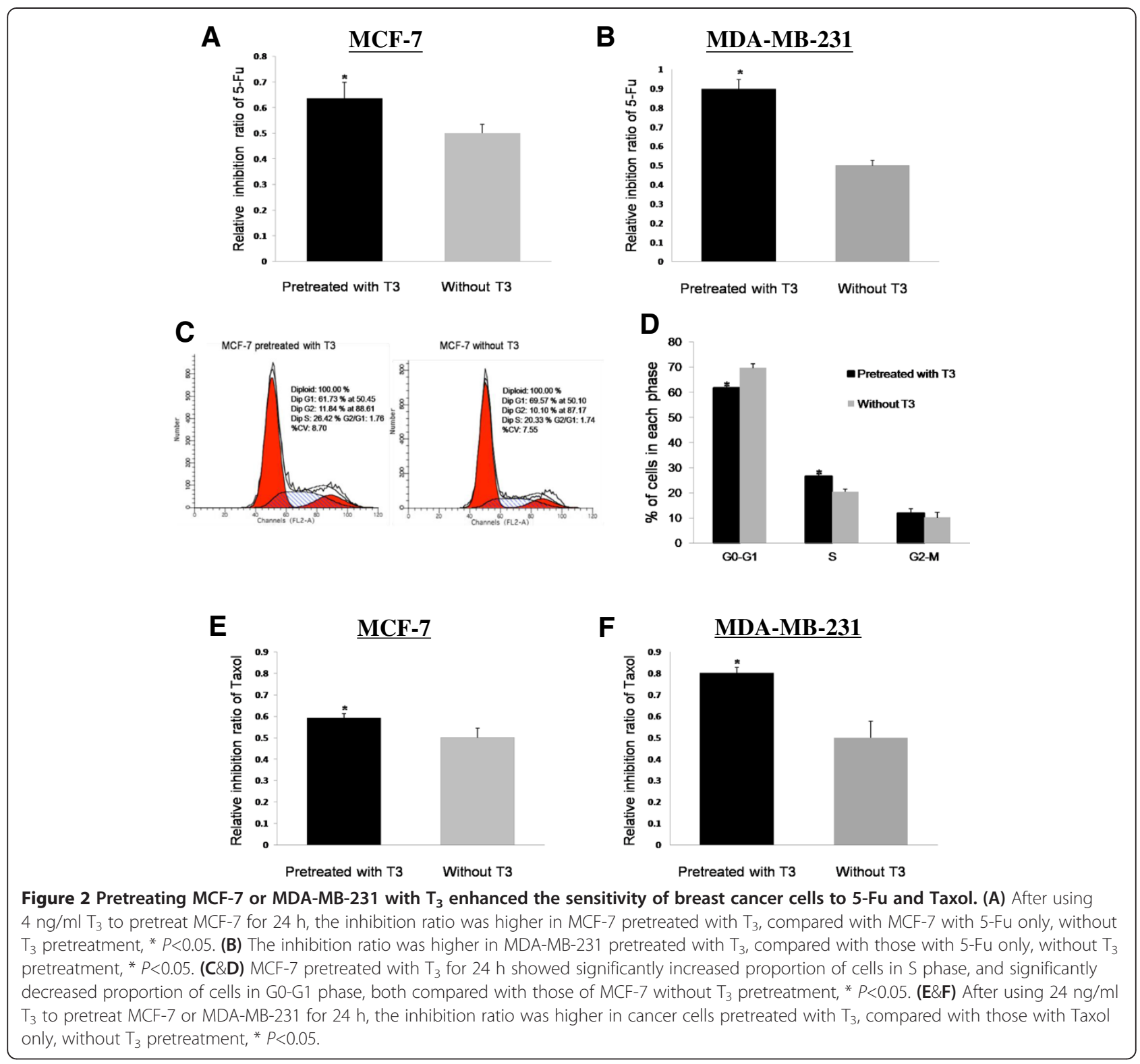

[15], marked by reductions in both thyroid function and peripheral conversion of $T_{4}$ to $T_{3}$, presumed to reflect a homeostatic mechanism to conserve energy. TSH levels tend to be normal or slightly decreased in these patients, but the underlying mechanism of reduced thyroid function is unknown. In this study, the NTIS prevalence in breast cancer patients at initial diagnosis was higher than that in breast benign lesions patients $(16.5 \%$ vs 7.3\%). The high NTIS prevalence in breast cancer patients at initial diagnosis suggests that NTIS may be related with malignancy. Furthermore, it was found in this study that the mean concentration of $\mathrm{FT}_{3}$ in breast cancer patients at initial diagnosis was significantly lower than that in breast benign lesions patients, suggesting that thyroid hypofunction may occur in breast cancer patients. Galton VA [16] studied the effect of malignant tumor on the thyroid function in rats, implanted with Walker 256 carcinosarcoma cell line, results showed a reduction in the concentration of $\mathrm{T}_{4}$ in tumorous rats serum, compared with corresponding control rats, due to the increased deiodination and urinary excretion.

The causes for hypothyroidism in cancer patient may not only be associated with tumor necrosis factor, interleukin-1, interferon- $\gamma[17,18]$, which inhibits the function of hypothalamus-pituitary-thyroid axis and peripheral conversion of $\mathrm{T}_{4}$ to $\mathrm{T}_{3}$, but also be associated with the self-protection mechanism, reducing the tissue metabolism to suppress the tumor growth. 


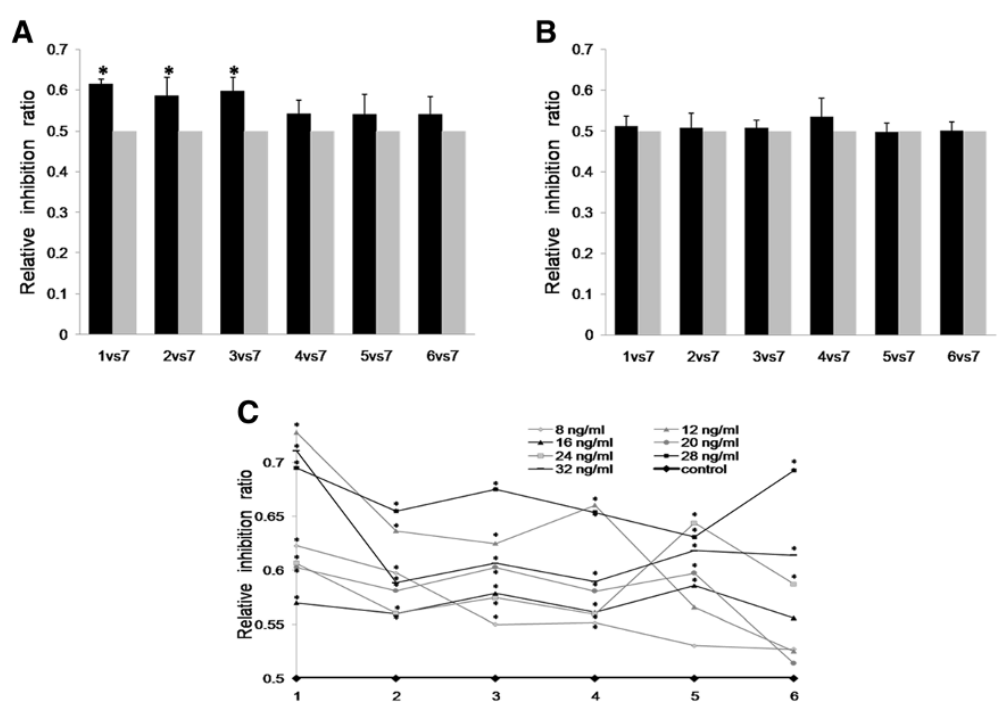

Figure 3 The effect of different usage modes of $\mathrm{T}_{\mathbf{3}}$ on sensitivity of MCF-7 to 5-Fu. (A) Only sensitivity of MCF-7 to 5-Fu in the 1 st to 3 rd groups pretreated with $4 \mathrm{ng} / \mathrm{ml} \mathrm{T}$ significantly increased, compared with that in group treated with 5-Fu only (7th group), ${ }^{*} P<0.05$; No significant difference of inhibition ratio was found between each of the 4 th to 6 th groups and 7 th group, ${ }^{*} P>0.05$. (B) Pretreament MCF-7 with $2 \mathrm{ng} / \mathrm{ml} \mathrm{T}$ did not show significant difference of inhibition ratio between each of 1 st to 6 th groups and 7 th group, ${ }^{*} P>0.05$. (C) The inhibition ratio of different usage modes of $T_{3}$, which ranged from $8 \mathrm{ng} / \mathrm{ml}$ to $32 \mathrm{ng} / \mathrm{ml}$. The sensitivity of MCF-7 to 5 -Fu in the 1 st to 3 rd groups pretreated with $T_{3}$ all significantly increased, ${ }^{*} P<0.05$; The MCF-7 in 4th to 6th groups successively showed significantly increased chemosensitivity, compared with that of 7 th group, ${ }^{*} P<0.05$, as the $T_{3}$ dose elevating from $8 \mathrm{ng} / \mathrm{ml}$ to $32 \mathrm{ng} / \mathrm{ml}$.

\section{Alteration of thyroid function of breast cancer patients during chemotherapy}

Chemotherapy is one of the most effective systemic therapies for cancers. In cancer patients, thyroid function is thought to be vulnerable to chemotherapy, as hypothalamic-pituitary axis is active and chemotherapy is systemic therapy for patients. The influence of chemotherapy on thyroid function was just seen as a late effect, mainly presenting hypothyroidism. Only few studied the alterations of thyroid function during chemotherapy, which induced abnormalities in thyroid hormones metabolism with a significant decrease in serum $\mathrm{T}_{3}$ concentration (NTIS) instead of overt thyroid disease in malignant hematologic disease [19]. Thyroid hypofunction was thought to be associated with inhibition of the liver thyroglobulin secretion [20] and hypothalamus-pituitary-thyroid axis function [7] by chemotherapy.

In this study, NTIS prevalence in breast cancer patients obviously increased during chemotherapy, compared with that at initial diagnosis $(87.1 \%$ vs $16.5 \%)$ and then decreased to $15.4 \%$ before the next chemotherapy (prechemotherapy). The NTIS prevalence reduction from $16.5 \%$ to $15.4 \%$ indicated that chemotherapy alleviated the NTIS prevalence, as thyroid hypofunction is considered as risk for breast cancer occurrence [21] and poor prognosis [22], this also suggests that NTIS alleviation may be a good efficacy by chemotherapy. With significantly increased NTIS prevalence during chemotherapy, whether controlling it is better for enhancing chemotherapeutic efficacy is unclear.

Furthermore, during chemotherapy for breast cancer patients in this study, significant decreases of $\mathrm{T}_{3}, \mathrm{~T}_{4}, \mathrm{FT}_{3}$ and TSH were found, compared with prechemotherapy $(P<0.05)$. After chemotherapy, thyroid function began to recover, and there was no significant difference between two consecutive prechemotherapies $(P>0.05)$, which indicated obvious thyroid function decreasing caused by chemotherapy mainly occurred during chemotherapy.

While there is still no detailed study on whether decrease of thyroid function goes against breast cancer chemotherapy or not. Decrease of thyroid function does not occur in all patients with malignant tumors during chemotherapy. In a prospective study, effects of chemotherapy on thyroid function in patients with nonseminoma testicular carcinoma were evaluted: Serum HCG was present in sixteen patients and absent in fifteen. HCG levels ranged from 10 to $30,000 \mu \mathrm{g} / \mathrm{l}$, with a median value of $520 \mu \mathrm{g} / \mathrm{l}$. And during chemotherapy, $\mathrm{T}_{4}, \mathrm{~T}_{3}$ and $\mathrm{rT}_{3}$ levels increased significantly, but basal TSH levels and the TSH response to thyrotropin releasing hormone (TRH) decreased. Furthermore, after chemotherapy the increased $\mathrm{T}_{4}$ and lowered TSH levels returned to normal, while the $\mathrm{FT}_{3}$ level did not change either during or after chemotherapy [3], which suggested an unaltered hypothalamic / pituitary axis. Non-seminomatous germ-cell tumors (NSGCT) can comprise several different histological components, among 
which, choriocarcinoma, produces HCG. In NSGCT patients with high-serum HCG levels, hyperthyoidism has been recognized and is considered to be a paraneoplastic phenomenon. Hyperthyroidism frequently accompanies NSGCT with highly elevated HCG [23]. Recent investigations have clarified the structural homology not only in the HCG and TSH molecules but also in their receptors, and this homology suggests the basis for the reactivity of HCG with the TSH receptor [24,25]. Hyperthyroidism or increased thyroid function has been reported in many patients with trophoblastic tumors [26], either hydatidiform mole $[27,28]$ or choriocarcinoma [25], for which the principal therapy is chemotherapy. With effective chemotherapy, their long term survival exceeds 95\% [24,29]. Furthermore, hyperthyroidism can be cured after the healing of the trophoblastic tumors [30]. Meister LH et al. reported a 26-year-old pregnant woman suffered from choriocarcinoma with metastases to both lungs. HCG were more than $2.5 \times 10^{6} \mathrm{mU} / \mathrm{ml}$. Consistent with HCG-induced hyperthyroidism, the patient suffered from thyroid crisis with fever of $38.6^{\circ} \mathrm{C}$, worsening respiratory distress, tachycardia of $140 \mathrm{bpm}$ and mental confusion during the first cycle of chemotherapy. Then the patient was treated with antithyroid crisis, symptomatic and supportive treatments. After the 10th cycle of chemotherapy the patient was in good condition and free of metastatic lesions in her chest X-ray [5]. It was reported that thyroid hormones could significantly promote the tumor growth and metastases [31]. The effective chemotherapy of curable tumors (such as malignant hydatidiform mole, choriocarcinoma, etc.) may be associated with hyperthyroidism during chemotherapy, which may enhance the chemotherapeutic sensitivity by inducing tumor cells progression from G0G1 phase into $S$ phase or elevating the mitochondrial activity. While, in this study, thyroid function decreased significantly and majority of the breast cancer patients suffered NTIS during chemotherapy, which may be associated with decreased chemotherapy sensitivity. Therefore, based on the above analysis, it was hypothesized that increasing the thyroid function by giving thyroid hormones before and / or during chemotherapy to imitate the hyperthyroidism or high thyroid function state of some choriocarcinoma patients during chemotherapy may enhance the chemotherapeutic efficacy in breast cancer and other malignant tumor patients who suffer obviously decreased thyroid function or NTIS during chemotherapy.

\section{Effect of triiodothyronine on chemosensitization}

The effect of thyroid hormones on chemotherapeutic efficacy has been rarely researched before, and whether adding thyroid hormones during chemotherapy is suitable for breast cancer patients is still unknown. Some studies found hypothyroidism may be the protective factor for cancers, as hypothyroidism can suppress tumor growth [32], in addition, Hercbergs et al. found that hypothyroidism could reduce the insulin-like growth factor 1, the antagonist of tamoxifen-induced cytotoxicity, to prolong the survival in recurrent high grade glioma patients [33]. This above mentioned perspective is different from our hypotheses, since we think hyperthyroid function is beneficial for treatment efficacy when patients receive chemotherapy. If patients of cancers reveive no chemotherapy, the status of hypothyroidism will be better for prognosis. Choriocarcinoma is curable with chemotherapy only, long term survival of these patients exceeds 95\%, the underlying mechanism may refer with high levels of HCG, which can induce hyperthyroidism [6]. In contrast, we firstly found thyroid hormones decreasing and NTIS prevalence increasing during chemotherapy in breast cancer patients, however, growth of breast cancer cells is regulated by thyroid hormones [34], thyroid hormones are considered to be the growth factor for glioma and thyroid cancer [35], the absence of thyroid hormones in cells could provoke a proliferation arrest in G0-G1 [36] or weak mitochondrial activity [12], which makes tumor cells insensitive to chemotherapy.

Basing on these points, we performed $\mathrm{T}_{3}$ chemosensitization test in breast cancer cells. The normal $\mathrm{FT}_{3}$ concentration in human body is $2.2-4.2 \mathrm{ng} / \mathrm{ml}$, we take the physiological concentration range of $\mathrm{FT}_{3}$ as the reference standard. Therefore, $4 \mathrm{ng} / \mathrm{ml} \mathrm{T}_{3}$ was used firstly in cell culture medium which contains no thyroid hormones, to evaluate whether the physiological concentration of $\mathrm{T}_{3}$ can elevate the chemotherapeutic efficacy. 5-Fu, the chemotherapeutic regent mainly focusing on tumor cells in $\mathrm{S}$ phase, is a usual component in chemotherapy for breast cancer. The $T_{3}$ pretreatment induced MCF-7 increased progression from G0-G1 phase to S phase, with elevated chemosensitivity to $5-\mathrm{Fu}$, the similar result was found in MDA-MB-231. Taxol works differently by arresting the breast cancer cells in G2-M phase, it enhances the polymerization of tubulin to stable microtubules and also interacts directly with microtubules, stabilizing them against depolymerization by cold and calcium, which readily depolymerize normal microtubules, so cells treated with taxol are unable to form a normal mitotic apparatus. To prove $\mathrm{T}_{3}$ can sensitize the breast cancer cells to Taxol, we used $24 \mathrm{ng} / \mathrm{ml} \mathrm{T}_{3}$ to pretreat MCF-7 or MDA-MB-231, the results showed that both MCF-7 and MDA-MB-231 pretreated with $\mathrm{T}_{3}$ were more sensitive to Taxol than those with Taxol only, without $\mathrm{T}_{3}$ pretreatment.

Both MCF-7 and MDA-MB-231 express the thyroid hormone receptor, the chemosensitization role of $\mathrm{T}_{3}$ in 


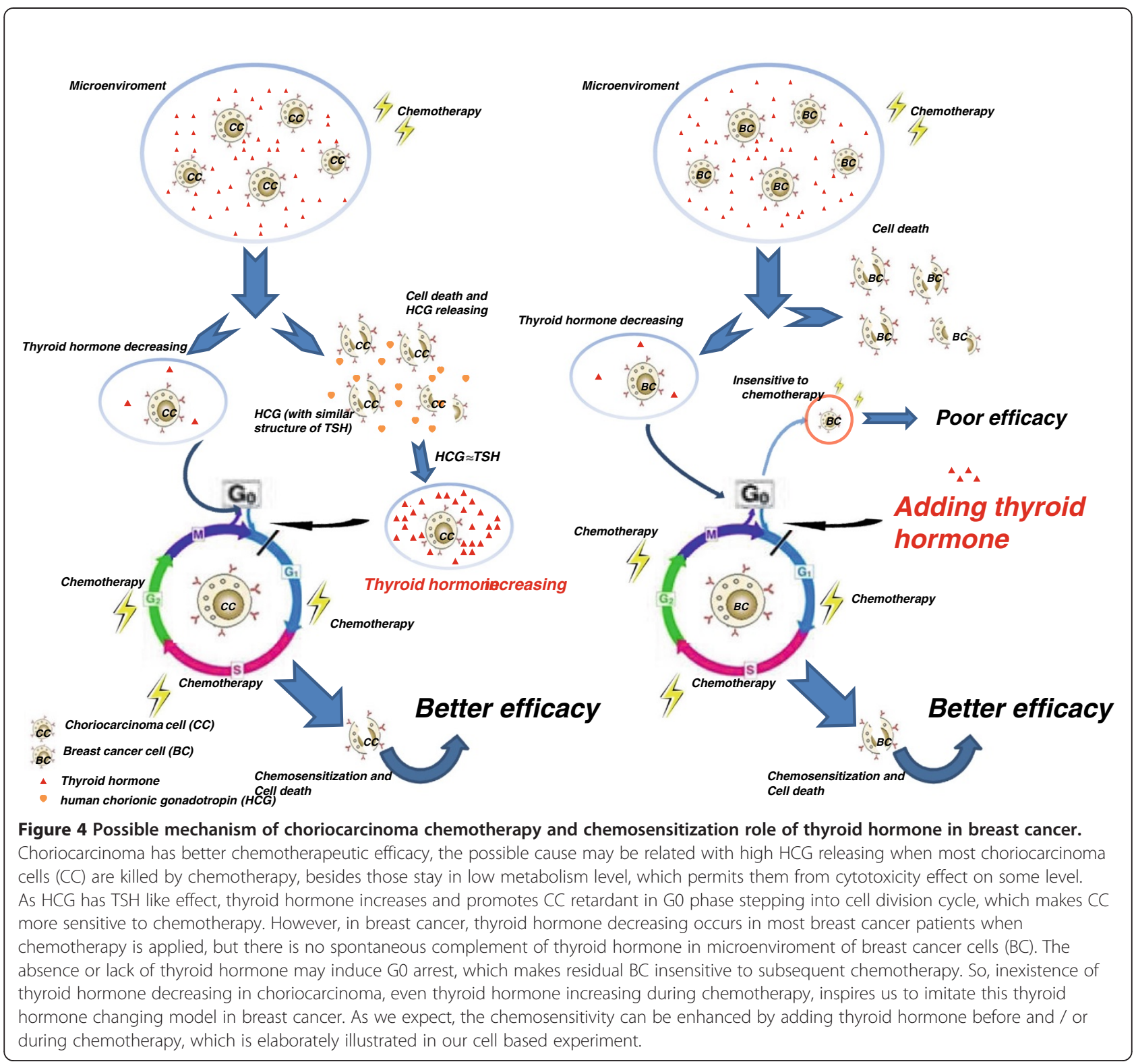

these two cell lines is thought to be mediated by the proliferation efficacy of $T_{3}$. In MCF-7, an estrogen receptor positive breast cancer cell line, the proliferative effect of thyroid hormone is not only initiated through the combination with the thyroid hormone receptor, but also through the combination with the estrogen receptor [37]. There are specific mechanisms that explain why thyroid hormone stimulate cell proliferation in gastric cancer cells, the cyclin/cyclin-dependent kinase levels and activity are involved [11]. Dinda et al. [38] found thyroid hormone not only enhances the phosphorylation of $\mathrm{pRb}$, but also induces the c-Myc expression and mutant P53 expression, this can also explain the cell proliferation efficacy of thyroid hormone. MDA-MB-231 is acknowledged harboring P53 mutations, which further demonstrates that thyroid hormone may promote the cell proliferation. Furthermore, thyroid hormone was found to sensitize the mitochondrial pathway to enhance the chemotherapeutic efficacy in MDA-MB-231 [12].

Thyroid hormone exerts its non-genomic and genomic actions in breast cancer cells [12]. For non-genomic action, which is characterized by combination of thyroid hormone and membrane receptors such as ER to elucidate the downstream signaling cascade, and is independent of transcriptional activity [39]. For genomic action, thyroid hormone primary mode is by binding to the thyroid hormone receptor in the nucleus then influencing the transcription and expression patterns of target genes. In MCF-7, which expresses ER and thyroid receptor, the chemosensitization role of $\mathrm{T}_{3}$ is mediated through the 
genomic and non-genomic actions of $\mathrm{T}_{3}$, while in MDAMB-231, which expresses thyroid receptor, the enhanced chemotherapeutic efficacy can also be contributed to the genomic and non-genomic actions of $\mathrm{T}_{3}$, like the influence on genes expression and the elevated mitochondrial activity mentioned above.

In light of the findings mentioned above, $\mathrm{T}_{3}$ may be used as adjuvant therapy for breast cancer patients in the future, the main points for its application are usage dose and how to combine it with chemotherapy. To imitate different usage modes of $\mathrm{T}_{3}$ in clinic, six individual groups with treatment by $\mathrm{T}_{3}$ and 5 -Fu were set up to separately compare with control group treated with $5-\mathrm{Fu}$ only. It is indicated in this results that, to get chemosensitization efficacy, pretreatment with lower dose of $T_{3}$, using higher dose of $T_{3}$ together with 5 -Fu or during chemotherapy with 5-Fu were all thought to be available. In clinic, however, using higher dose of $\mathrm{T}_{3}$ will increase the risk of suffering thyroid crisis, and in most of $\mathrm{T}_{3}$ chemosensitization tests from $4 \mathrm{ng} / \mathrm{ml}$ to $32 \mathrm{ng} / \mathrm{ml}$, the relative inhibition ratio in 1st group was highest, except $\mathrm{T}_{3}$ at $16 \mathrm{ng} / \mathrm{ml}$ and $24 \mathrm{ng} / \mathrm{ml}$. So, pretreatment with lower dose of $\mathrm{T}_{3}$ until the end of chemotherapy may be a safer and more efficient therapy for breast cancer patients. In addition, only a suitable dose of $\mathrm{T}_{3}$ could have chemosensitization role in chemotherapy, treatment with extremely low dose of $\mathrm{T}_{3}$ for long time $(72 \mathrm{~h})$ still could not enhance the chemosensitivity of MCF-7 to 5-Fu.

Using $\mathrm{T}_{3}$ for chemosensitization in breast cancer therapy is to simulate the high thyroid function in choriocarcinoma patients during chemotherapy, based on the new findings that thyroid hormones decreasing during chemotherapy, in which chemotherapeutic regents mainly take effect.

In summary, we studied the thyroid hormones and NTIS in breast patients at initial diagnosis and during chemotherapy, in which with a thyroid function significant decreasing, and found $\mathrm{T}_{3}$ enhanced the chemosensitivity of MCF-7 to 5-Fu. Moreover, we think the chemotherapeutic efficacy partly depends on the thyroid function, checking the thyroid function in breast cancer patients is important for elevating chemotherapeutic efficacy.

\section{Conclusion}

Therefore, it was hypothesized, in this article, that through imitating the high thyroid function or high endocrine hormone state of some choriocarcinoma patients during chemotherapy, the chemosensitivity may be enhanced by giving thyroid hormones or other endocrine hormones to the patient before and / or during chemotherapy, which may bring a new therapy to breast cancer and other malignant tumors. This new therapy, extremely different from the traditional concept of endocrinochemotherapy (i.e., chemotherapy plus endocrinotherapy), might be termed as hormono-sensitizing chemotherapy (HSCT), endocrinosensitizing chemotherapy (ESCT), or neo-endocrinochemotherapy (NECT). The detailed mechanisms are included in Figure 4 [40]. If the hypothesis mentioned above proves to be clinically safe and feasible, NECT might replace the current chemotherapy in future.

\section{Abbreviations}

NTIS: Non-thyroidal illness syndrome; $T_{3}$ : Triiodothyronine; $T_{4}$ : Thyroxine; $\mathrm{rT}_{3}$ : Reverse triiodothyronine; $\mathrm{FT}_{3}$ : Free triiodothyronine; $\mathrm{FT}_{4}$ : Free thyroxine; TSH: Thyroid stimulating hormone; anti-TPO: Thyroperoxidase antibody; antiTg: Thyroglobulin antibody; 5-Fu: 5-fluorouracil; CCK8: Cell counting kit-8; ESS: Euthyroid sick syndrome; HCG: Human chorionic gonadotrophin; TRH: Thyrotropin releasing hormone; NSGCT: Non-seminomatous germ-cell tumors; HSCT: Hormono-sensitizing chemotherapy; ESCT: Endocrinosensitizing chemotherapy; NECT: Neo-endocrinochemotherapy.

\section{Competing interests}

The authors declare that they have no competing interests. No reimbursements, fees, funding, or salary was received from an organization that may in any way gain or lose financially from the publication of this manuscript now and in the future. We don't hold any stocks or shares in an organization that may in any way gain or lose financially from the publication of this manuscript now and in the future. We don't hold and currently applying for any patents relating to the content of the manuscript. We didn't receive reimbursements, fees, funding, or salary from an organization that holds or has applied for patents relating to the content of the manuscript. We don't have any other financial competing interests. The authors declare that they have no non-financial competing interests.

\section{Authors' contributions}

All the authors have made substantial contribuations to this work, JH, LJ, GJ and LX equally contributed to this study. JBH performed the basic research, did statistical analysis and drafted this manuscript. LJ, GJ, LX recorded thyroid function results, CX and XX helped to collect data and analyze it. HL directly participated in the whole process throughout the research and statistical analysis. As corresponding author, LK and GR designed and coordinated this research and provided guidance throughout this process. All authors read and approved the final manuscript.

\section{Acknowledgments}

We thank all the medical staff of our department for assistance with data collection and Tingxiu Xiang for providing breast cancer cell lines.

Received: 4 October 2012 Accepted: 30 June 2013

Published: 6 July 2013

\section{References}

1. Paulides M, Dorr HG, Stohr W, Bielack S, Koscielniak E, Klingebiel T, Jurgens $\mathrm{H}$, Bolling $\mathrm{T}$, Willich $\mathrm{N}$, Sauer $\mathrm{R}$, et al: Thyroid function in paediatric and young adult patients after sarcoma therapy: a report from the Late Effects Surveillance System. Clin Endocrinol (Oxf) 2007, 66(5):727-731.

2. Ogilvy-Stuart AL, Shalet SM, Gattamaneni HR: Thyroid function after treatment of brain tumors in children. J Pediatr 1991, 119(5):733-737.

3. Willemse PH, Sleijfer DT, Sluiter WJ, Koops HS, Doorenbos H: Alterations in thyroid hormone metabolism during chemotherapy in patients with testicular carcinoma. Clin Endocrinol (Oxf) 1982, 16(3):303-313.

4. Hsieh TY, Hsu KF, Kuo PL, Huang SC: Uterine choriocarcinoma accompanied by an extremely high human chorionic gonadotropin level and thyrotoxicosis. J Obstet Gynaecol Res 2008, 34(2):274-278.

5. Meister LH, Hauck PR, Graf H, Carvalho GA: Hyperthyroidism due to secretion of human chorionic gonadotropin in a patient with metastatic choriocarcinoma. Arq Bras Endocrinol Metabol 2005, 49(2):319-322.

6. Cooper DS: Hyperthyroidism. Lancet 2003, 362(9382):459-468. 
7. Majkowska-Mlynarczyk A, Kinalski M, Zaczek-Kucharska E: The thyroid gland function assessment in women after mastectomy and chemotherapy during breast cancer therapy. Endokrynol Pol 2007, 58(5):397-402.

8. Kumar N, Allen KA, Riccardi D, Bercu BB, Cantor A, Minton S, Balducci L, Jacobsen PB: Fatigue, weight gain, lethargy and amenorrhea in breast cancer patients on chemotherapy: is subclinical hypothyroidism the culprit? Breast Cancer Res Treat 2004, 83(2):149-159.

9. Conzemius MG, Graham JC, Haynes JS, Graham CA: Effects of treatment with growth hormone and somatostatin on efficacy of diammine [1,1-cyclobutane dicarboxylato (2-)-0,0']-(SP-4-2) in athymic rats with osteosarcoma. Am J Vet Res 2000, 61(6):646-650.

10. Wang Y, Li J, Cui Y, Li T, Ng KM, Geng H, Li H, Shu XS, Liu W, Luo B, et al: CMTM3, located at the critical tumor suppressor locus $16 q 22.1$, is silenced by $\mathrm{CpG}$ methylation in carcinomas and inhibits tumor cell growth through inducing apoptosis. Cancer Res 2009, 69(12):5194-5201.

11. Barrera-Hernandez G, Park KS, Dace A, Zhan Q, Cheng SY: Thyroid hormoneinduced cell proliferation in GC cells is mediated by changes in G1 cyclin/cyclin-dependent kinase levels and activity. Endocrinology 1999, 140(11):5267-5274.

12. Suhane S, Ramanujan VK: Thyroid hormone differentially modulates Warburg phenotype in breast cancer cells. Biochem Biophys Res Commun 2011, 414(1):73-78

13. DeGroot LJ: "Non-thyroidal illness syndrome" is functional central hypothyroidism, and if severe, hormone replacement is appropriate in light of present knowledge. J Endocrinol Invest 2003, 26(12):1163-1170.

14. Rubenfeld S: Euthyroid sick syndrome. N Engl J Med 1978, 299(25):1414

15. Jonckheer MH, Blockx P, Broeckaert I, Cornette C, Beckers C: 'Low T3 syndrome' in patients chronically treated with an iodine-containing drug, amiodarone. Clin Endocrinol (Oxf) 1978, 9(1):27-35.

16. Galton VA, Ingbar SH: Effect of a malignant tumor on thyroxine metabolism and thyroid function in the rat. Endocrinology 1966, 79(5):964-970.

17. Poth M, Tseng YC, Wartofsky L: Inhibition of TSH activation of human cultured thyroid cells by tumor necrosis factor: an explanation for decreased thyroid function in systemic illness? Thyroid 1991, 1(3):235-240.

18. Pang XP, Yoshimura M, Hershman JM: Suppression of rat thyrotroph and thyroid cell function by tumor necrosis factor-alpha. Thyroid 1993, 3(4):325-330.

19. Nellen Hummel H, Gutierrez Espindola G, Talavera J, Gordon F, Halabe J, Flores G: Effect of chemotherapy on thyroid hormone concentration in patients with malignant hematologic diseases. Arch Med Res 1997 28(2):215-217

20. Kano T, Kojima T, Takahashi T, Muto Y: Serum thyroid hormone levels in patients with fulminant hepatitis: usefulness of $\mathrm{rT3}$ and the $\mathrm{rT3} / \mathrm{T} 3$ ratio as prognostic indices. Gastroenterol Jpn 1987, 22(3):344-353.

21. Kuijpens JL, Nyklictek I, Louwman MW, Weetman TA, Pop VJ, Coebergh JW: Hypothyroidism might be related to breast cancer in post-menopausal women. Thyroid 2005, 15(11):1253-1259.

22. Yokoe T, lino Y, Takei H, Horiguchi J, Koibuchi Y, Maemura M, Ohwada S, Morishita Y: Relationship between thyroid-pituitary function and response to therapy in patients with recurrent breast cancer. Anticancer Res 1996, 16(4A):2069-2072.

23. Oosting SF, de Haas EC, Links TP, de Bruin D, Sluiter WJ, de Jong IJ, Hoekstra HJ, Sleijfer DT, Gietema JA: Prevalence of paraneoplastic hyperthyroidism in patients with metastatic non-seminomatous germcell tumors. Ann Oncol 2010, 21(1):104-108

24. Hershman JM: Physiological and pathological aspects of the effect of human chorionic gonadotropin on the thyroid. Best Pract Res Clin Endocrinol Metab 2004, 18(2):249-265.

25. Yoshimura M, Hershman JM: Thyrotropic action of human chorionic gonadotropin. Thyroid 1995, 5(5):425-434

26. Hershman JM: Hyperthyroidism induced by trophoblastic thyrotropin Mayo Clin Proc 1972, 47(12):913-918.

27. Yoshimura M, Pekary AE, Pang XP, Berg L, Goodwin TM, Hershman JM: Thyrotropic activity of basic isoelectric forms of human chorionic gonadotropin extracted from hydatidiform mole tissues. J Clin Endocrinol Metab 1994, 78(4):862-866.

28. Higgins HP, Hershman JM, Kenimer JG, Patillo RA, Bayley TA, Walfish P: The thyrotoxicosis of hydatidiform mole. Ann Intern Med 1975, 83(3):307-311.

29. Fisher PM, Hancock BW: Gestational trophoblastic diseases and their treatment. Cancer Treat Rev 1997, 23(1):1-16.
30. Rajatanavin R, Chailurkit LO, Srisupandit S, Tungtrakul S, Bunyaratvej S: Trophoblastic hyperthyroidism: clinical and biochemical features of five cases. Am J Med 1988, 85(2):237-241.

31. Kumar MS, Chiang T, Deodhar SD: Enhancing effect of thyroxine on tumor growth and metastases in syngeneic mouse tumor systems. Cancer Res 1979, 39(9):3515-3518.

32. Cristofanilli M, Yamamura Y, Kau SW, Bevers T, Strom S, Patangan M, Hsu L, Krishnamurthy S, Theriault RL, Hortobagyi GN: Thyroid hormone and breast carcinoma. Primary hypothyroidism is associated with a reduced incidence of primary breast carcinoma. Cancer 2005, 103(6):1122-1128.

33. Hercbergs AA, Goyal LK, Suh JH, Lee S, Reddy CA, Cohen BH, Stevens GH, Reddy SK, Peereboom DM, Elson PJ, et al: Propylthiouracil-induced chemical hypothyroidism with high-dose tamoxifen prolongs survival in recurrent high grade glioma: a phase I/II study. Anticancer Res 2003, 23(1B):617-626.

34. Richard GM, Gabriel NH, Thomas A: Neoplasms of the Breast. In Cancer Medicine, Volume 2. 6th edition. Edited by Donald WK, Raphaele P, Ralphr W, Robert CB, Ted SG, James FH, Emil F. Frei: BC Decker; 2003:1889.

35. Yalcin M, Bharali DJ, Lansing L, Dyskin E, Mousa SS, Hercbergs A, Davis FB, Davis PJ, Mousa SA: Tetraidothyroacetic acid (tetrac) and tetrac nanoparticles inhibit growth of human renal cell carcinoma xenografts. Anticancer Res 2009, 29(10):3825-3831.

36. Porlan E, Vega S, Iglesias T, Rodriguez-Pena A: Unliganded thyroid hormone receptor beta1 inhibits proliferation of murine fibroblasts by delaying the onset of the G1 cell-cycle signals. Oncogene 2004, 23(54):8756-8765.

37. Cestari SH, Figueiredo NB, Conde SJ, Clara S, Katayama ML, Padovani CR, Brentani MM, Nogueira CR: Influence of estradiol and triiodothyronine on breast cancer cell lines proliferation and expression of estrogen and thyroid hormone receptors. Arq Bras Endocrinol Metabol 2009, 53(7):859-864.

38. Dinda S, Sanchez A, Moudgil V: Estrogen-like effects of thyroid hormone on the regulation of tumor suppressor proteins, p53 and retinoblastoma, in breast cancer cells. Oncogene 2002, 21(5):761-768.

39. Davis PJ, Davis FB, Lin HY, Mousa SA, Zhou M, Luidens MK: Translational implications of nongenomic actions of thyroid hormone initiated at its integrin receptor. Am J Physiol Endocrinol Metab 2009, 297(6):E1238-1246.

40. Huang J, Ji G, Xing L, Li H, Wang Z, Ren G, Wu K, Kong L: Neoendocrinochemotherapy: a novel approach for enhancing chemotherapeutic efficacy in clinic? Med Hypotheses 2013, 80(4):441-446.

doi:10.1186/1471-2407-13-334

Cite this article as: Huang et al.: Implication from thyroid function decreasing during chemotherapy in breast cancer patients: chemosensitization role of triiodothyronine. BMC Cancer 2013 13:334

\section{Submit your next manuscript to BioMed Central and take full advantage of:}

- Convenient online submission

- Thorough peer review

- No space constraints or color figure charges

- Immediate publication on acceptance

- Inclusion in PubMed, CAS, Scopus and Google Scholar

- Research which is freely available for redistribution 